\title{
Lansky Performance Status 90
}

National Cancer Institute

\section{Source}

National Cancer Institute. Lansky Performance Status 90. NCI Thesaurus. Code C69425.

Minor restrictions in physically strenuous activity. 